\title{
Examining Barriers to Internationalisation Created by Diverse Systems and Structures in Vocational Education and Training
}

\author{
Angela Joy Shaw*, Kieron John Shaw, and Suzanne Blake \\ University of Hull, School of Education, Faculty of Art, Culture and Education, Cottingham \\ Road, Hull, HU6 7RX, United Kingdom
}

Received: 03.03.2016; Accepted: 23.04.2016; Published: 24.08.2016

\begin{abstract}
In a global society, all educational sectors need to recognise internationalism as a core, foundational principle. Whilst most educational sectors are taking up that challenge, vocational education and training (VET) is still being pulled towards the national agenda in terms of its structures and systems, and the policies driving it, disadvantaging those who graduate from VET, those who teach in it, and the businesses and countries that connect with it. This paper poses questions about the future of internationalisation in the sector. It examines whether there is a way to create a VET system that meets its primary point of value, to produce skilled workers for the local labour market, while still benefitting those graduates by providing international skills and knowledge, gained from VET institutions that are international in their outlook. The paper examines some of the key barriers created by systems and structures in VET to internationalisation and suggests that the efforts which have been made to address the problem have had limited success. It suggests that only a model which gives freedom to those with a direct vested interest, students, teachers, trainers and employers, to pursue international co-operation and liaison will have the opportunity to succeed.
\end{abstract}

Keywords: Internationalisation, Vocational Education and Training, VET Systems, VET Structures

\footnotetext{
${ }^{*}$ Corresponding author: a.shaw@hull.ac.uk
}

ISSN: 2197-8646

http://www.ijrvet.net 


\section{Introduction: The resistance to internationalism in vocational education and training (VET)}

In the 21st century, labour is internationally mobile as never before in history (Servais, 2007; Munz, 2013), and having international experience and skills lies at the core of personal development. This not only demands of education that it is international in practical terms, the global viability of the courses and awards it provides, the global outlook of its course content, the mobility of its graduates, but in structural ones. Its institutions need to be internationally connected.

There is a wide range of factors creating barriers to internationalisation in vocational education and training (VET) relating to issues of social class and mobility, culture, history and political orientation but this paper will focus on one area in particular; the impact of the national and local focus on systems and structures in the sector. Currently VET, across the globe, remains largely locked in the character of a national service serving economic, social and cultural goals. In this paper we will argue that, whilst the latter of these is important, it is the fundamental economic goals which provide the impetus for VET's direction of travel in relation to policy. In part, this is inevitable because the sector faces uniquely local pressures and the scope of its provision will always be steered by local political and economic needs; the practical skills it teaches unavoidably influenced by the same, as well as by levels of economic development locally. This national focus has had benefits but the ultimate outcome of it, when considering internationalisation, is threefold:

\subsection{Institutional solipsism}

VET institutions are unable to co-operate fully on international research; nor can its practitioners, lecturers, researchers and instructors easily liaise with comparable teachers in other countries to conduct occupational benchmarking, learn new skills, and raise the overall standards of the sector, partly because of intensive practical workloads, but also because partnership is more difficult in such a diverse sector; they do not know who the comparable practitioners in other countries are, or how their work might compare to their own. There are currently very few mechanisms in place to connect them, nor are there clear systems of comparability of national courses and qualifications.

\subsection{Labour mobility}

The lack of clear comparability of courses across the world hits learners too; as a result, its awards and qualifications are rarely internationally recognised, or transferable. In the 12 months leading up to September 2014, for example, the UK had 271,000 new migrant workers. (Office for National Statistics, 2015). Yet, according to the OECD, 17.8\% of people in the country are working in professions for which they are over-qualified, such as skilled engineers working as taxi drivers; skilled nurses working as house cleaners. It states: 
„In all OECD countries [...] immigrants are more likely to be over-qualification [sic] than persons born in the country. These results are consistent with those of Battu and Sloane (2002) in the United Kingdom on over-qualification among ethnic minorities (particularly Indians), relating primarily to problems with diploma recognition and discrimination" (OECD, 2007).

Those holding VET qualifications frequently find the international mobility of their labour and qualifications problematic and are less able to transfer, and fully utilise, their skills in a global marketplace (Aldin et al., 2010). The term skills is, in itself, problematic. As Ruhs (2011) points out:

"Although commonly used in academic, public and policy discourse, the term skills is a very vague term both conceptually and empirically. It can refer to a wide range of qualifications and competencies whose meaning in practice is not always clear"(Ruhs, 2011, p. 59).

For the purposes of this discussion, the term skills is used in the way in which UK vocational qualification awarding bodies define it, as the practical can do aspect of a vocational qualification. It is often these practical skills in vocational learning that make internationalisation inherently difficult to achieve in VET, since the skills are often the most resolutely local element. It is a subtle challenge; having trained in their given trade or occupation, these learners will have obtained the same underpinning knowledge and understanding of their subject area as similarly qualified VET graduates in every other country. Their skills, in contrast, will have been developed according to national political and economic demands and local business needs. Being practical qualifications, they will also inevitably have been shaped by the levels of economic development in their country of study. All these factors may put their skills, and therefore the applicability of their qualifications, at variance with those required in the country to which they are travelling.

A simple example can be provided with reference to agriculture; to become an agricultural worker, the underpinning knowledge required in basic botany, zoology, animal husbandry, seed propagation and land management will be universal across all countries. Of necessity, however, an agricultural student in Angola will have learnt a very different set of skills from an agricultural student in England, France, Australia or the USA. The former's economic environment might demand wheat farmers working in clay-based soil, as well as real life experience in how to deal with locust storms. Its levels of economic development would also dictate that they can also deploy these skills with limited access to water and on a sparse budget. Angola's VET colleges, being locally responsive, would provide for all of this. Western countries, in contrast, might need dairy farmers practised in loamy, arable soil, with a focus on BSE-prevention and high-yield milk production, and the skills to use multi-million-pound machinery, and its VET colleges and awarding bodies would develop course competencies in response to this need.

These issues give rise to a situation where those with VET qualifications face barriers to the global transferability of their qualifications (and therefore barriers to the 
transfer of their labour) not necessarily faced by those with school or higher education qualifications.

\subsection{Economic waste}

There is also detriment to the labour market VET graduates are entering. In today's world of wide-scale levels of immigration, it is an economic waste that a high proportion of VET qualifications are going unused by new migrants because they are unrecognised in their new country of residence. As Sandford and Lumley (2006) point out, with reference to the UK:

„Enabling migrants to reach their potential and to fully utilise their skills and expertise is good for them and good for the UK economy. Indeed significant savings to the public purse can be made if more resources were put towards retraining this potentially untapped resource"(Sandford and Lumley, 2006, p. 42).

This national focus creates some of the key barriers to internationalisation in VET and explains why they remain so intractable, despite the advantages internationalism would bestow on staff, employers, learners, businesses, the economy and wider society. The main question, however, is whether they are unavoidable; whether, because VET is constitutionally a national system, anything more can be done to drive greater internationalism alongside it.

A single article clearly cannot set out to provide an exhaustive examination of such a large area of investigation, but it can undertake a discourse by looking at the problems currently being encountered, and some of the efforts that have been tried in recent years to overcome them. It can suggest how and why these efforts have had limited success and how lessons from these endeavours could point to a new way forward.

\section{Is vocational education and training an inherently national entity?}

A series of interlaced pressures ensure that, in countries around the world, VET's provision is consistently pulled towards the national agenda rather than an international one. In part, this national focus is rooted in institutional and structural complexities within the VET sector itself, not least that every country in the world has its own unique system of vocational education, making international integration a bureaucratic minefield. At its source, however, this national pull is cultural; and in many Western countries it is the result of VET's founding purpose over a century ago. The contemporary outside interests, political, social and economic, that continue to define VET's culture as that of a servant of the national agenda (Richardson and Wiborg, 2010) can be discerned as having four distinct underlying causes: 


\subsection{Local commercial influences}

It is in VET's basic constitution to serve the national economic interest. Local commercial demands, and the government's political blueprint for the national economy, are perhaps the most significant drivers of VET's provision in each country in which it operates. From its earliest foundation, VET was primarily designed as a country's way of fuelling its own real economy with skilled labour and, around the world, it has largely remained in this existential space ever since. In contrast to the knowledge economy or academic objectives of higher education, VET is, primarily, designed to foster and grow the skills that are responsive to the nation's commercial interests; to service the country's trade and industries, its exports and its high streets, with skilled labour, thereby encouraging inward investment and providing the foundational economic structure of the country. It has therefore almost never had the same primary educational goals as other forms of education: to expand the mind; to provide maximised opportunities; to create more rounded individuals. These elements of education are still seen as the primary goal of statutory schooling and higher education, but, primarily, VET is designed and encouraged to deliver specific practical skills for specific vocational opportunities in the local region.

\subsection{National political involvement}

Being perceived as the fuel of the real economy inevitably makes VET a highly political entity and therefore subject to national political pressures. Regular political interventions at the national level in England and Wales bear testament to this, although they are often little more than exercises in playing to vote-winning fears about skill shortages and promises of expanding apprenticeship schemes. Any idealised vision of VET courses, qualifications, institutions and cultures breaking out of their national focus and coordinating in a new, international paradigm unravels further. The political establishment's goal in intervening in VET is not to build skilled workers for the international stage, nor to build apprenticeships with international applicability; it is to improve the nation's economic prospects according to their own national plans.

Given the premise that national economic and political pressures shape VET provision, there is, of course, the vexed question of the extent to which national economic and political drivers are truly national anymore. VET may find itself beholden to the policy decisions of successive national governments and their economic plans for the nation, but it can be argued that, in itself, this situation is anachronistic in a global economy. If a national government's economic blueprint for VET is almost wholly designed to sell its country to that global economy, then one could argue that these national political interventions in VET are a response to the global marketplace and therefore are, in reality, international pressures, albeit mediated through the conduit of the national government. Thus, if VET provision in the UK's car building regions suddenly expand their courses in automotive engineering in response to local commercial demand, it is likely that this demand is the presence of multinational companies in the region. So, what seems, prima facie, to be local employment forces on VET are, upon further investigation, 
in fact the forces of international commerce. In truth, however, even though the market pressures are coming from multinational companies, these forces are not pushing VET to produce internationally applicable skills and qualifications. The pressure is still for VET institutions to create local jobs.

A multinational car manufacturer's presence in the UK exerts no market pressure to create engineers who can work in car factories in Seoul, Sochaux or Turin. Whatever pressure they create for local VET colleges is only that they produce workers for the local plant.

It could be argued, therefore, that the forces of international commerce, far from widening the international value of VET, are actually further constricting it to the local paradigm and multinational companies are, in this sense, shaping regional economies. The same is true of the global market forces driving national government policy interventions: The global market is determining the contours of the local economy around the VET institutions, and thus it is the local economy to which VET is responding. Therefore, even apparently international forces on VET seem only to embed deeper localism.

\subsection{Economic status of host country}

A country's underlying levels of economic development will also have an impact on the skills and competencies VET delivers. This constricts their courses and qualifications further within national borders or, at the very least, within socio-economic borders. This is both because a country's underlying economic development will shape the basic capabilities of the teaching institution and because the employment market in different economic regions will differ accordingly. Put simply, an agricultural college student in Nebraska is likely to have to learn to use a $\$ 10$ million combine harvester to get a job after graduation, and his/her college is likely to make provision for it in his/her learning; an agricultural student in Bangladesh is not, and nor is the college likely to be able to afford the use of one for teaching.

It is not just a matter of expensive machinery. VET is practical education, and the practical reality of jobs varies significantly from country to country. This all shapes the skills that graduates must learn, and the competencies VET institutions must teach and measure.

In many ways, of course, those in poorer countries are often likely to get a more immersive and lasting education in the fundamentals of their profession, something those in wealthier countries are likely to only learn as theory. The interplay of these social and economic pressures upon VET was highlighted recently in a UNESCO-UNEVOC forum posting. A VET tutor in India had tried to create a set of skill standards for his electrician apprentices, and was required to model them on those available in England, the USA and Australia. He said:

„I have attempted to bench mark the Skill Standards of Indian Electricians (Industrial not domestic) and the results I got initially confused me as Indian Electricians fared much better in a few Skills that their counterparts in an highly advanced 
Country. My further exploration made me understand the Electrician in the advanced country will not like to repair the Part (say a motor) but will simply replace it, whereas the Electrician in lesser developed country will retrieve parts from here and there and work on that. Surely, it makes an economic sense in Advanced Country to go in for replacement as the Cost per hour of the two technicians varies a lot" (UNESCO-UNEVOC, 2013).

This example serves to illustrate how the different environments in which VET operates shape the course content and inevitably lead to differences in skills training. This then has compound impacts on the qualifications VET institutions provide, and what they measure, and therefore how transferable they are.

\subsection{Cultural norms and anomalies}

The social, cultural, racial, religious, atmospheric, topographical and environmental nature of the VET institution's home country is likely to have a marked impact on its structures and the skills and competencies its students learn. Trainee hairdressers in African and Caribbean countries might graduate never having learned to cut Caucasian hair, because there is no local need for it. Trainee Hindu chefs in India might never have learned to cook beef. Those in Western Europe might have no knowledge of Halal or kosher preparation. Again, it should be noted that national contours shape all sectors of education, not just VET. But because of the practical, local-jobs-related nature of VET, and because the practical skills are what VET qualifications validate, it is a situation that is grossly amplified in this particular sector.

\section{The impact of VETfls localism on its graduates and institutions}

VET is nationally focused like no other form of education, but without this national focus, it would not be delivering the unique things it does so well: to be a nationally responsive education system, at the service of the national economy, delivering to national employment needs. However, such thinking leads to a conundrum. The most visible and harmful result of this situation is at the level of qualifications: VET graduates find they very often cannot transfer their acquired qualifications outside their home country (Ure, 2015).

This lack of internationalism then has significant and harmful repercussions on the local economy and the local labour market, ironically, two of the greatest forces keeping VET local. In the UK alone, according to Rienzo of the National Institute of Economic and Social Research, the number of foreign-born people of working age increased from 2.9 million in 1993 to over 6 million in 2013 but, as she points out, , a significant share of relatively recent migrants have taken up employment in less skilled occupations in the UK" and "groups of foreign-born workers [...] are known to be frequently employed in jobs that do not correspond with their education and skills" (Rienzo, 2014). Likewise 
Maas (2013) presents compelling qualitative evidence of Poles who are unable to use their vocational qualifications in the UK and have to take up employment in low-skilled work in the horticultural and domestic sectors. A study with a slightly different focus undertaken in 2013 (Altorjai, 2013) showed that immigrant workers in Britain were more likely to be over-qualified than indigenous British workers for the work they were doing.

The situation is not restricted to the UK but is evident throughout the world. As Cerna (2011) points out:

"more than $33 \%$ of Indian nationals were overqualified [for their jobs] in Canada in 2000 (OECD 2007, p. 142). Many of them worked as taxi drivers. OECD research indicates that qualified immigrants encounter difficulties in all countries [...] (OECD 2007, p. 134). Over-qualification rates vary among countries, ranging from 5\% (Czech Republic) to 26\% (Spain). The UK is placed in a group with Spain, Ireland and Belgium, where the over-qualification rates are high for immigrants and for the native-born"(Cerna, 2011).

This lack of an international focus can therefore be seen to have an impact in many countries and research across the world has highlighted the same problems of lack of engagement in a wide range of countries. Almost twenty years ago Tessaring (1998) reported that VET students across Europe were failing to respond to opportunities for international mobility, and, more recently, Duquenne et al. reported that, in France, "[...] apprentices do not have information or skills enough about existing mobility tools to make the most of them,, (Duquenne et al., 2012, p. 9). Nor is the problem confined to Europe; Smith et al. (1999) and Harris et al. (2009) have all identified similar issues in Australian VET and although their research was ten years apart, they found that the barriers to internationalization remained constant.

Apart from the human impact of this, skilled individuals locked out of gaining employment in their given area of expertise, it is an economic waste for countries with significant levels of immigration. The transferability of vocational qualifications across national boundaries is therefore of paramount importance to both students and our national economies, and yet is seemingly fraught with difficulty. VET's resolutely national focus puts vocational education and training in an invidious position in the 21st century. As Clark and Winch (2007) point out:

"[...] the trans-European and indeed trans-continental mobility of labour means that different qualities and skills of labour increasingly confront each other, leading to ever louder calls for international recognition of skills and qualifications" (Clark and Winch, 2007, p. 2).

In terms of the impact on the institutions in the modern world, research in education is undertaken on a global scale, usually in partnership and liaison with those who are in the same business in other countries. With vocational education, these things become problematic, principally because systems are so locally-oriented that simply for VET teachers to find equivalent educationalists and courses in other nations is almost 
impossible. Yet such research is increasingly needed to give vocational learners the best possible opportunities (Rauner and Maclean, 2008). There are, of course, a small number of eminent researchers focusing on VET, but these tend to be people who work in universities or for government agencies and produce theoretical analyses of the subject. Practitioners on the ground in the world of VET, liaising with each other and sharing ideas and practice, co-operating on front-line activities and undertaking joint research into common problems are almost non-existent.

\section{A national skills system in an international labour economy: Can VET be fit-for-purpose in the 21st century?}

It needs to be acknowledged that the problems caused by poor internationalisation in VET are well recognised in some areas and steps have been taken in recent years to try to address them. With the economic and political drivers seemingly an indivisible part of its nature, these solutions have instead looked at least to align the structures, courses and qualifications in VET worldwide, to create something approaching a universal model, or set of models. Finding equivalence between courses and awards, and enabling the transferability of qualifications, have been the fundamental goals. One such effort to create a more unified system in VET and to address the issue of transferability of qualifications has been within the European Union (EU) with the Copenhagen Process and Bruges Communiqu (EU, 2011). Yet even in the relatively confined group of EU countries involved in these negotiations, there has been little progress in aligning their systems and structures. As the 2011 Bruges Communiqu bulletin says:

"As players on the global education market, national VET systems need to be connected to the wider world in order to remain up-to-date and competitive. [...] Although a European area of education and training is emerging, we have still not achieved our original objective of removing obstacles,, (European Union, 2011, p. $11)$.

Between 2008 and 2012, the EU took this a step further, creating a European Qualifications Framework (EQF) which set out to map qualifications, including VET qualifications, across the continent. In reality, an examination of the framework reveals little detail relating to VET at all, instead showing simply a meagre approximation of each country's "ladder, of qualifications, with single summary sentences to define entire suites of qualifications, and many of the entries relating to academic qualifications rather than VET (https://ec.europa.eu/ploteus/en/compare).

Some of the latest efforts have included the work of the UNESCO International Centre for Vocational Education and Training in Germany. Its aim was to focus global expertise in VET in one location in an attempt to aid transparency, assist mobility, foster research and create a more unified sector. Unfortunately none of these can be said to have been achieved, given that the latest (2014) UNESCO-UNEVOC TVET database holds details 
of the systems of 205 different countries across the globe, every one of them unique in terms of its systems and underlying political and policy-driven funding and structure. (http://www.unevoc.unesco.org/worldtvetdatabase.php?lang=)

Despite their efforts, these bodies have been unable to create international cohesion in VET, principally due to the disparities, misalignments and incompatibilities between the intrinsic structures of all national VET systems.

The sheer size and complexity of VET, across the world, make it difficult to wrestle down into a single, coherent model even within one country. This structural complexity has created what Anderson (2008, p. 106) describes as "a large and amorphous sphere of provision,.. England, for example, has more people engaged in VET than in any other single sector of education. In 2011-12, Further Education (F.E.) in England had a total of 5.37 million students (Skills Funding Agency Data Service, 2013), double the number in higher education (2.66 million students), and more than in either secondary school (3.85 million children) or primary school (4.43 million) (DfE, 2013). Whilst F.E. as a sector covers a wide range of training, not simply that which can be classified as VET, it is the major provider of VET qualifications in England and this represents the core of its business.

At present there are 1,780 vocational qualifications offered by 176 awarding bodies in England and Wales (UKCES, 2013) and within each one of these are large numbers of units of competence in different skills areas, and all offered in countless different ways. Multiply this size and complexity by the number of countries offering VET qualifications, and the fundamental impossibility of a single, cohesive international framework becomes readily apparent.

When systems and structures in other countries across the world are examined, it becomes apparent that they are both as complex as in England and Wales, and as shaped by local and national contours. In some places vocational education is almost entirely delivered by employers under the control of a central administrative bureau of the government. In other places, it is delivered in colleges that are entirely confined to pre-university-level education; in others, in institutions that are half-way houses between colleges and universities. In many countries, vocational education begins as a phase of statutory schooling. In a majority of countries, young people are divided at some stage during their secondary schooling into "academic,, and "vocational," strands, undertaking their final years of statutory education in a school whose curriculum reflects those two different foci (UNESCO-UNEVOC, 2013). This is true not only in European countries such as Denmark, Holland, Germany, France and Greece, but also in Brazil, Russia, Kazakhstan and many others, all of which have competitive-entry academic schools, and vocational schools for those unable or unwilling to enter such academic schools. In some countries, vocational education and training is provided by subject-specific institutions, giving rise to the Beauty School, the Art College, the Business College and, in some cases, specific trade schools attached to large companies, such as the Henry Ford Trade School set up by the Ford Motor Company to train its workforce. This is especially true in the USA, where the system of vocational education and training is further complicated by having national systems and state systems running alongside each other, with substantial private vocational training interwoven into both. The systems 
outlined here are, of course, ones that are provided by, or sanctioned by, the state. In addition, in many countries, there are numerous informal channels of vocational education and training. For example, in Pakistan, the Ustad-Shagird system, a longestablished system which entails trainees entering a workplace and learning a trade entirely by watching and practising the skills, runs alongside formal state systems. This form of vocational training exists throughout much of Africa and Asia and is deeply rooted in local customs and traditions.

Allied to these differences in national systems, the historical foundations have frequently grown from very different bases. In some countries the trade union movement was historically active in promoting VET in the first instance and continues to be a force in its development (Hopkins 2013); in some countries there is a strong element of caste underlying which jobs different groups of people are allowed (or not allowed) to train to undertake (Medelsohn and Vicziani, 1998); in some countries there are strong historical ties to former colonial powers and their preferred systems (Bude, 1983; Cummings, 1999). As Ball says:

"One of the commonest assertions to be found in accounts of schooling in less developed countries in Africa is that the present day education systems of these countries are trapped and inhibited in their development, by the legacies of the colonial past,, (Goodson and Ball, 2012, p. 117).

In addition the different economic climates across the world ensure that some VET has to be primarily responsive to employers and markets (a typical situation in the USA) whilst in other countries it is more responsive to political control relating to wider national strategies. Alongside the historically driven differences are culturally and socially driven differences in systems and structures; in some parts of the world there are still jobs (and therefore training for jobs) which are designated as men's work or women's work (Doumato and Posusney, 2003). In a similar vein, the age at which children leave school to begin work or training for work has substantial variation across the world.

The problems all of this structural complexity brings are embodied in one recent attempt to find cohesion between VET systems across borders. As a precursor to the advent of the EQF in 2012, Brockman et al. (2011), funded by the Nuffield Foundation, produced an in-depth analysis of VET in four European countries England, Germany, the Netherlands and France. The study examined VET in the four countries at the structural level, analysing how the educational systems differed in when and how they were presented; and at the level of educational expectation, exploring what the four countries expected learning outcomes to look like and how the curricula differed or remained similar. It also looked in more detail at four distinctly different occupational contexts to try to uncover any cross-national synthesis. They examined lorry driving, bricklaying, software engineering and nursing. In all four cases, the authors found considerable divergence in the structure and delivery of the qualifications, the expectations of trainers and the underlying anticipated educational outcomes. These relatively similar near-neighbours had such different structures and systems that the authors found 
it almost impossible to identify any cross-national synthesis between them. The study concluded that the proposal to launch the EQF would be fraught with difficulty as the differences in the underlying systems, structures, concepts and expectations were significant, in what was a relatively homogenous group of countries.

All of this complexity disables VET graduates from taking jobs overseas. Prospective employers in other countries have no idea what their qualifications mean in the local context, and the skills graduates have acquired (versus their knowledge) may not be transferable. For teachers and instructors, quite apart from the lack of provision and mechanisms available to them, most VET teachers struggle simply to understand what equivalence there is in other countries to their job, or their courses, or the qualification levels they teach. This hampers the ability of VET practitioners to professionalise further through research and cooperation.

\section{The philosophical questions for consideration}

The historical imperatives, the nature of global business competition, national political intervention, and the localised nature of much VET training have all served to make efforts at international unification see little success. Yet the need to provide ways to overcome the barriers is more critical than ever. Thus we come to the central paradoxes. Vocational education and training is, of necessity, flexible and intensely adaptable to local needs: national policy, local economic conditions, business and industry opportunities will all continuously shape its delivery. For VET to be the best it can be, specifically means it must operate hand-in-hand with industry and government, and change direction at short notice to react to commercial and trade opportunities arising in different localities; to be therefore diverse and expansive in course content, and flexible in its skills and qualification offerings. Yet this very quality of local adaptability undermines the qualifications it produces in a global marketplace.

We can say that VET's core purpose is to be locally responsive; and that the more locally responsive its skills, qualifications and courses become, the more it becomes impossible to locate them in an international paradigm, and the less relevant this increasingly makes them in a shrinking world. The same paradox applies to VET institutions themselves. Their success rests on their ability to be responsive to national economic and local business needs by producing appropriately skilled graduates, and to do so by developing courses that are resolutely local. Yet in the act of realising these goals, those institutions impede their ability to advance their own capabilities and deliver worldleading research and collaboration, by preventing them being able to tap into a well of universal global knowledge.

So the conceptual paradox at the heart of VET institutions is that in order to survive and thrive and deliver, they need to be responsive to their local markets. But the more responsive to those local needs they are, the less they are able to take part globally in leading research and knowledge exchange because the parameters are different country to country, and therefore the less they are able to ensure that their teaching is the best it can be. In other words, the better a VET institution gets at delivering its primary 
point of value, graduates skilled for national employment requirements, the less it is able to get better by tapping into the well of international knowledge and global standards.

\section{New routes: Facilitation not bureaucratisation}

As outlined earlier, a variety of well-intentioned attempts have been made to promote greater integration and internationalisation in VET. These have almost always involved work by supranational entities working to create a single, unified system to be used internationally, to foster transferability of qualifications through the imposition of skillmatching matrices and ladders of linked qualifications. They have all faced significant barriers, arguably because these attempts all represent an effort to bureaucratise and consolidate what is, by economic, political and social necessity, an organic and fluid local system.Better progress, however, has been made when individual industries themselves work on the challenge in more contained areas. For example the EU-funded Bolster Up Project has made significant progress in creating a Europe-wide set of qualifications for those involved in the furniture-making industries (http://www.furnitureprofessions.eu/).

The welding industry provides an equally good example: The qualifications for welding have now gained universal recognition in many countries, largely thanks to the global players in the oil industries. As a consequence, there is now a set of international standards for welding It should be recognised that it is not a perfect system, singular and universally applied, nor immune to VET's persistent localism: The international standards still run alongside sets of standards from the country or region, such as the American Petroleum Institute Standards, the Australian/New Zealand Standards, the European Union Standards and the British Standards. Advertisements for welding jobs across the world frequently list not only the international requirements but also include, in parentheses, the acceptability of various overlapping national ones that indicate the same level of skill.

Nevertheless the progress with welding and furniture shows that co-operation is possible where there is a will to create it. It also shows that when specific employer interests pull for coordination and cooperation, more progress is made than when central bodies try to push frameworks upon them from above. Practically, it also shows that when individual industries are each the drivers of international integration in their own sectors, more progress is made than when a country's entire system of VET is examined with a view to co-ordinating it with another's entire VET system.

Perhaps the top-down imposition of international frameworks onto national policies and systems and structures, themselves based on understandable national interests, are actually serving to suppress what could be a more dynamic bottom-up approach to internationalising VET, driven by those with the greatest interest in differentiating standards of qualification. The major question is whether national governments would countenance relinquishing some of their hold on VET policies and systems, letting the individual practitioners, employers and businesses take hold of the problem and solve it industry by industry. But with the possibilities for international collaboration offered by global com- 
munications technology, these pull models should be possible as never before. In relation to the international transferability of current VET qualifications, what seems to be most needed is a bridge to carry qualified people from their country of origin to their country of destiny. In order to do this countries around the world need to grow more link qualifications. This would mean governments, awarding bodies and VET institutions working collaboratively with the specific remit of providing such bridging programmes across a range of VET sectors, allowing people to transfer their original qualifications into ones acceptable in the new country of residence. Link qualifications are already established practice in a few places in the world. For example, in Australia there is a government department in New South Wales which assesses overseas VET qualifications and points new arrivals in the direction of link programmes (NSW government department, National Office of Overseas Skills Recognition [NOOSR] www.aphref.aph.gov.au-housecommittee-mig-recognition-subs-sub084.pdf).

Structural issues aside, the underpinning of any change must come in the very culture of VET. Its institutions and teachers need to see internationalism as a core principle, and be guided towards this thinking, with appropriate facilities put in place to allow it to happen. Currently, that provision is meagre with VET institutions dealing endlessly with tight funding regimes which necessitate staff teaching heavy workloads and few, if any, bodies available to provide funding for international research and collaboration. Even within these constraints, however, more could be done and Australasia once again provides a potential model for the future. In New Zealand, an online research forum has been created (https://akoaotearoa.ac.nz/ako-aotearoa/akoaotearoa/resources/pages/about-ako-aotearoa-website) dedicated to VET staff, thereby making full use of digital technology. It is restricted to national VET staff and has limited functionality in terms of matching people, but the model does provide a vision of what could be achieved on an international scale. With current technology, it is possible to create an online social networking site for VET staff from across the world automatically matching their skills and research interests and putting them in contact with one another (as www.linkedin.com or www.researchgate.net do for other professionals).

This would allow teachers to build a personal profile page listing their skills, teaching areas and research interests. Although there is already an international UNESCOUNEVOC forum for VET staff, it uses outdated technology and is really a simple message-board. A full social networking site, in contrast, could use intelligent algorithms to match staff with similar interests across the world, so that groups of likeminded and like-skilled VET teachers would be brought together automatically, and could share ideas and collaborate on an international platform. In the private sector, exactly this kind of application is already widely used to enable communication and collaboration between global staff in multinational companies. In June 2014, current usage of these commercial platforms, known as an Enterprise Social Networks, was estimated by research organisation Frost Sullivan at 208 million people worldwide (http://www.frost.com/c/10077/sublib/display-report.do?id=ND0E-01-00-00-00). 


\section{Conclusion}

If vocational education and training is to embrace internationalisation alongside its core business of meeting local and national needs then much more needs to be done to unify the sector across the world. As long as VET's learners are unable to transfer their qualifications across borders and its staff unable to access opportunities to collaborate internationally, then the sector is under-serving itself and its graduates.

Vocational education and training is supposedly the front line of the sort of advanced skills that will give a country an economic advantage. Yet, in an internet-enabled and socially networked world, where the key economic differentiator, for a business, a government, a skilled person, increasingly lies in global connectivity, its structures and systems are consigning it to an analogue model in a digital world. In short, the more that nations push VET down local and national paths, the more they undercut its value by depriving it of the greatest of all economic and social advantages in today's world: internationalism.

The world needs highly skilled VET-qualified workers as never before. Those workers need to be able to go where their skills are most wanted. Those who teach them need to be able to co-operate and share their skills and knowledge with others in the same sector in other parts of the globe in order to provide their trainees with a truly international perspective. Only with new ways of addressing the current barriers will we be able to achieve these outcomes. 


\section{References}

Altorjai, S. (2013). Over-qualification of immigrants in the UK - Institute for Social and Economic Research (ISER). Colchester: University of Essex.

Aldin, V., James, D. \& Wadsworth, J. (2010). The Changing Shares of Migrant Labour in Different Sectors and Occupations in the UK Economy: An Overview. In: Ruhs M., \& Anderson B. (Eds.), Who Needs Migrant Workers? Oxford: Labour Shortages, Immigration, and Public Policy (OUP).

Anderson, D. (2008). Productivism, Vocational and Professional Education, and the Ecological Question, Vocations and Learning, 1(1), 105-129. Dondrecht: Springer.

Brockman M., Clarke L., \& Winch C. (2011). Knowledge Skills and Competence in the European Labour Market. Whats in a Vocational Qualification? London: Routledge.

Bude, U. (1983). The adaptation concept in British colonial education. Comparative Education, 19(3), pp.341-355.

Cerna, L. (2011). Selecting the Best and Brightest Migration Observatory University of Oxford. Available at: http://www.mi-grationobservatory.ox.ac.uk/policyprimers/selecting-best-and-brightest

Accessed March 2016.

Clark, L. \& Winch, C. (2007). Vocational Education International Approaches, Developments and Systems. Oxford: Routledge.

Cummings, W.K., (1999). The institutions of education: Compare, compare, compare! Comparative education review, 43(4), 413-437.

Department for Education (2013). School and Pupil Numbers Available at: https://www.gov.uk/government/collections/statistics-school-and-pupil-numbers. Accessed May 2016.

Doumato, A. \& Posusney P.M. (2003). Women and Globalization in the Arab Middle East: Gender, Economy, and Society. Boulder: Lynne Rienner Publishers.

Duquenne, L., Toutain O., \& Gaucher A. (2012). Research on Internationalisation and Mobility in VET Materials, numbers and needs: French National Report. Available at http://www.inthemc-project.org/. Accessed March 2016.

European Union (2011). Supporting vocational education and training in Europe: the Bruges Communiqu. Luxembourg: Publications Office of the European Union.

Goodson, I.F. \& Ball S. (2012). Defining the Curriculum: Histories and Ethnographies. London: Routledge.

Harris, R., Simons, M. \& Maher, K., (2009). New Directions in European Vocational Education and Training Policy and Practice: Lessons for Australia. A National Vocational Education and Training Research and Evaluation Program Report. Adelaide: National Centre for Vocational Education Research Ltd.

Hopkins, N. (2013). Citizenship and Democracy in Further and Adult Education. Dondrecht: Springer Science and Business Media. 
Maas, W. (2013). Democratic Citizenship and the Free Movement of People. Leiden: Martinus Nijhoff.

Mendelsohn, O. \& Vicziany M. (1998). The Untouchables: Subordination, Poverty and the State in Modern India, Cambridge:Cambridge University Press .

Munz, R. (2013). Demography and Migration An Outlook for the 21st Century. Migration Policy Institute Policy Brief No 4. Washington D.C.: Migration Policy Institute.

OECD (2007) International Migration Outlook. Available at http://www.oecd.org/ els-/mig/internationalmigrationoutlook2007.htm Accessed January 2016.

Office for National Statistics Migration Statistics Quarterly Report (2015). Available at http://www.ons.gov.uk/ons/rel/migration1/migration-statistics-quarterlyreport/february-2015/index.html. Accessed March 2016.

Rauner, F. \& MacLean, R. (2008). Handbook of TVET Research. Dondrecht: Springer.

Richardson, W. \& Wiborg, S. (2010). English Technical and Vocational education in Historical and Comparative Perspective. London: Baker Dearing Educational Trust.

Rienzo, C. (2014). Migrants in the UK Labour Market: An Overview. available at: www.migrationobservatory.ox.ac.uk/briefings/migrants-uk-labour-market-ov er-view. Accessed February 2016.

Ruhs, M. (2011). Who needs migrant workers? The potential role of an independent expert commission in future EU labour immigration policy. In Karlsson, J.O., \& Pelling, L. (Eds.), Moving Beyond Demographics Perspectives For A Common European Migration Policy. Stockholm: Global Utmaning.

Sandford, S. \& Lumley, T. (2006). Home Truths, New Philanthropy Capital, available at: www.thinknpc.org/publications/home-truths/. Accessed March 2016.

Servais, J.M. (2007). Working for Better Times. Rethinking work for the 21st century. International Labour Office.

Skills Funding Agency Data Service (2013). Available at https://www.gov.uk/government/statistics/learner-participation-out-comes-and-level-of-highest-qualification-held. Accessed February 2016.

Tessaring, M. (1998). Training for a Changing Society. A Report on Current Vocational Education and Training Research in Europe. Reference Document. Lanham: Behnan Associates.

UKCES Employer Skills Survey (2013). Available at: https://data.gov.uk/dataset/ ukces-employer-skills-survey-2013. Accessed January 2016.

UNESCO-UNEVOC (2013). Available at: http://www.une-voc.unesco.org/go.php. Accessed February 2016.

Ure, O.B. (2015). Governance for Learning Outcomes in European Policy-Making: Qualification Frameworks Pushed through the Open Method of Coordination. International Journal for Research in Vocational Education and Training (IJRVET) 2(4), 268-283. 


\section{Bibliographical notes}

Dr. Angela Joy Shaw is a lecturer in education at the University of Hull in the UK. Her special areas of research interest are VET, internationalisation and widening participation.

Kieron Shaw is an independent international researcher and specialist in corporate communication and organisational behaviour, working with companies such as IBM, Roche, Toyota, BP, Maersk and Unilever.

Suzanne Blake is a lecturer at the University of Hull in the UK. Her key focus is on widening participation, inclusion and vocational education. 